\title{
SOCIO-ENVIRONMENTAL IMPACTS OF LAND USE/COVER CHANGE IN ETHIOPIAN CENTRAL RIFT VALLEY LAKES REGION, EAST AFRICA
}

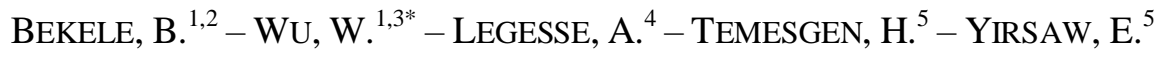 \\ ${ }^{I}$ College of Land Management, Nanjing Agricultural University, Nanjing 210095, China \\ (e-mail: B. Bekele-belewbekele@yahoo.com) \\ ${ }^{2}$ Department of Natural Resources Management, Assosa ATVET College, Assosa 242, Ethiopia \\ ${ }^{3}$ National and Local Joint Engineering Research Center for Rural Land Resources Use and \\ Consolidation, Nanjing 210095, China \\ ${ }^{4}$ Department of Geography and Environmental Studies, Dilla University, Dilla 419, Ethiopia \\ (e-mail: A. Legesse-abiyottura@gmail.com) \\ ${ }^{5}$ Department of Natural Resources Management, Dilla University, Dilla 419, Ethiopia \\ (e-mail: H. Temesgen-habte023@yahoo.com, E. Yirsaw-eshetu.yirsaw@yahoo.com) \\ *Corresponding author \\ e-mail:ww@njau.edu.cn; phone: +86-137-7065-1675 \\ (Received $27^{\text {th }}$ Jun 2018; accepted $13^{\text {th }}$ Sep 2018)
}

\begin{abstract}
Unregulated land use/cover change (LUCC) has imposed significant local, regional and global impacts on livelihood and environment, particularly in sub-Saharan Africa. Previous studies well documented the extent and drivers of such spectacular LUCC in East Africa. However, data on regional/local impacts particularly that combine its socioeconomic and environmental effects are very scanty currently. Hence, this study is aimed to assess the socio-environmental impacts of LUCC in more dynamic and fragile landscapes of the Ethiopian Central Rift Valley lakes region. We used a combination of data from Remote Sensing, GIS-based processing, household survey and meteorological stations to quantify and analyze LUCC impacts. Results indicated that a rapid LUCC has occurred in the region over the last three decades which imposed a number of socioeconomic and environment-related impacts. Based on the percentage of respondent farmers, climate change (95\%), soil productivity decline (94\%), land degradation (92\%), shortage of wood (91\%), shortage of grazing land (89\%), soil erosion (88\%), loss of biodiversity $(81 \%)$ and lake water retreat $(74 \%)$, are the principal impacts of LUCC perceived. Such perceived impacts of LUCC are in line with the observed results obtained from comprehensive measured data analysis. Future land use policies need to consider management options that work on reducing anthropogenic-induced pressures on the environment and encouraging livelihood diversification in order to minimize the adverse socio-environmental impacts of spectacular LUCC in the region.
\end{abstract}

Keywords: anthropogenic, climate change, household, land degradation, perception

\section{Introduction}

Anthropogenic activities have altered the planet Earth at unprecedented rates, magnitude and spatial scales since the beginning of human life on Earth (Turner et al., 1994) which made land change science to emerge as one fundamental component of global environmental change and sustainability research (Turner et al., 2007). These changes are complex in nature in space and time (Lambin et al., 2003). For instance, the changes could be land modification, subtle alterations in the attributes of a land cover or land conversion, the complete replacement of one cover type by another (e.g., forest 
land to cropland) (Lambin et al., 2003); or it could be land restoration, human intervention in the form of land cover maintenance and restoration (e.g. degraded land rehabilitation by area closure) (Wortley et al., 2013). Depending on the speed of change, other scientists also consider land changes as gradual or abrupt changes (Geist et al., 2006). Depending on the nature of these changes, the impact they imposed and the subsequent driver for the changes also varies in space and time.

Unregulated land use/cover change (LUCC) has multiple socio-environmental impacts that can significantly affect key aspects of Earth System functioning as well as human life on Earth (Chhabra et al., 2006). For instance, LUCC directly impacts biodiversity loss worldwide (Haines-Young, 2009; Carpio et al., 2016); it affects the carbon balance of terrestrial environments (Houghton and Goodale, 2004; Maharjan and Joshi, 2013); and is the primary source of land and land resources degradation (Meshesha et al., 2012; Matano et al., 2015). By altering ecosystem services (Polasky et al., 2011; Yirsaw et al., 2016), LUCC also affects the ability of biological systems to support human needs and hence affects livelihood systems (Mutoko et al., 2014). Furthermore, LUCC affects spatial landscape pattern and configuration (Pang et al., 2013; Wan et al., 2015). Such impacts of LUCC are more noticeable in developing countries where the livelihood of the majority of the population is directly dependent on natural resources and hence the environment is highly vulnerable to such changes (Lambin and Meyfroidt, 2011).

The other principal impact of anthropogenic-induced LUCC that has been well recognized in recent decades, and also given emphasis in this study, is its effect on local and regional climate change (Dirmeyer et al., 2010; Mutiibwa et al., 2014; Fan et al., 2015) as well as on global warming (Vitousek, 1994; Brovkin et al., 2004). It is known that LUCC affects climate mainly through an accumulation of greenhouse gases (GHG) (Houghton et al., 2012) which is partly originated from intensive agriculture and deforestation (Maharjan and Joshi, 2013). Studies show that LUCC also affects land surface temperature and surface moisture (Jiang et al., 2015; Pal and Ziaul, 2017), carbon balance of terrestrial ecosystems (Houghton and Goodale, 2004), and precipitation and evapotranspiration rates and hence the sustainability of hydrological and climatological systems (Liu et al., 2008). This indicates that in addition to natural factors, LUCC also plays a significant role in world climate change in general.

Natural variability and human activities are the main causes of climate change (Maharjan and Joshi, 2013). However, the contribution of human activities (e.g. LUCC) to climate change has increased from time to time. The increase in atmospheric concentration of GHGs is the major factor contributing to climate change caused by the human activities. For instance, according to Maharjan and Joshi (2013), energy sector, agriculture, land use change and forestry, and industrial process contribute to $68 \%$, $15 \%, 13 \%$ and $4 \%$ of global GHG emission respectively. This indicates next to energy sector emission, the carbon emission from the agricultural sector and land use change (e.g., deforestation and forest degradation) (Pacheco-Angulo et al., 2017) is about 28\%. Under increased deforestation, not only the amount of GHGs added to the atmosphere increase, but also the capacity of the remaining forest to serve as a sink to such gases is decreasing.

Although LUCC impacts were recognized globally, the degrees of such impacts are markedly different in various time, landscapes and regions. Hence, in sub-Saharan Africa, particularly East Africa, where both LUCC and climate change are the major environmental and livelihood concerns in recent decades (Lambin and Ehrlich, 1997; 
Houghton and Hackler, 2006), detail analysis of the socio-environmental impacts of LUCC has a paramount importance in contributing to future policy and management strategies. This is particularly true for the Central Rift Valley (CRV) lakes region of Ethiopia where a tremendous LUCC has occurred over the last three decades (Temesgen et al., 2013; Ariti et al., 2015). In Ethiopia, previous studies documented the extent and drivers of LUCC in different parts of the country (Tsegaye et al., 2010; Kindu et al., 2015; Bekele et al., 2018a; Temesgen et al., 2018). However, the studies on impacts of LUCC, particularly that combine socioeconomic and environmental effects, by comparing farmers' perceived results with the observed result from measured data analysis is very scarce currently. In this study, it is assumed that the perceived impact of LUCC by farmers is in line with the observed results from measured data analysis.

Hence, this study is intended to examine the socio-environmental impacts of LUCC by integrating Remote Sensing, GIS, socioeconomic and climatic datasets, using the fragile and most dynamic landscapes of the Ethiopian CRV lakes region as an ideal case study site. Such a combined study of socioeconomic, ecological and environmental impacts of LUCC helps to reduce the adverse effects and to devise appropriate policy intervention that works on the root drivers of spectacular LUCC.

\section{Materials and methods}

\section{The study area}

The Central Rift Valley Lakes Region is located about $170 \mathrm{~km}$ south of the capital city, Addis Ababa, Ethiopia which is specifically found in the limits of $38^{\circ} 20^{\prime}-38^{\circ} 50^{\prime}$ east longitude and $7^{\circ} 20^{\prime}-8^{\circ} 00^{\prime}$ 'north latitude (Fig. 1). It is situated in the current administrative regions of Oromia and Southern Nations, Nationalities and Peoples Region, and covers approximately an area of $13,401 \mathrm{~km}^{2}$. The area is topographically characterized by a depression zone with steep marginal faults along its edges and bounded by eastern and western highlands. The geological and geomorphologic features of the region are the results of Cenozoic volcano-tectonic and sedimentation processes (Ayenew, 2007; Macgregor, 2015). The Ethiopian CRV is part of the Great East African Rift Valley, that originates from Aden Junction (Arabian Plate) in the Middle East and continues in the direction of south-west, traversing longitudinally eastern African countries such as Djibouti, Eritrea, Ethiopia, Kenya, Uganda and Tanzania, and reaches to Mozambique (Hengsdijk and Jansen, 2006; Ayenew, 2007).

The climate of the CRV varies markedly with altitude and season (Jansen et al., 2007). It is humid to sub-humid in the highland portion and semiarid in the rift floor which is characterized by warm and wet summer, and dry, cold and windy winter. The study area receives a bimodal rainfall distribution pattern. The small rainy season (Belg) occurs between February and May (FMAM), which is followed by the main rainy season (Kirmet) that occurs from June to September (JJAS). Based on long-term data from four meteorological stations in CRV namely: Arsi Negele, Bulbula, Meki and Ziway, the mean rainfall is 252 and $386 \mathrm{~mm}$ for Belg and Kirmet season respectively, and the overall mean annual rainfall is about $740 \mathrm{~mm}$. The coefficient of variation for rainfall is higher for Belg season (31\%) than for Kirmet season (22\%). On the other hand, the minimum temperature of the study area ranges from its lower mean value $\left(11.5^{\circ} \mathrm{C}\right)$ for winter season (October to January) to its higher mean value $\left(14.2^{\circ} \mathrm{C}\right)$ for Kirmet season, while the maximum temperature ranges from its lower mean value 
$\left(25.9^{\circ} \mathrm{C}\right)$ for summer season to its higher mean value $\left(28.5^{\circ} \mathrm{C}\right)$ for Belg season. Rainfall in CRV is generally highly erratic which is one of the main constraints to rainfed agriculture in the region (Jansen et al., 2007).

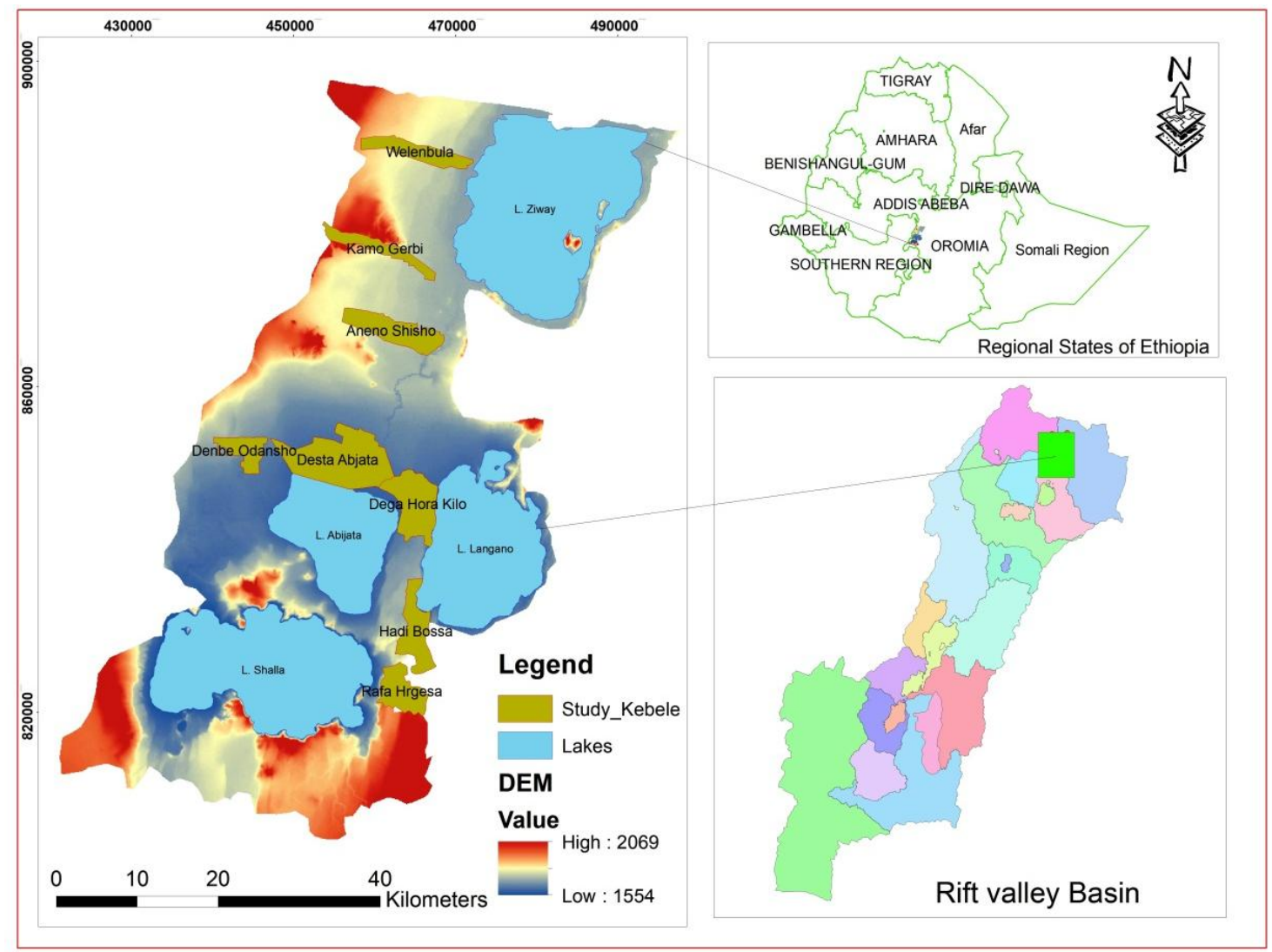

Figure 1. Location map of the study landscape with agroclimatic areas

The major land use/cover (LUC) types include agricultural land, dense and open acacia woodlands, water body, bush/shrubland, grazing land, swampy/marshy land and bare land (Bekele et al., 2018a). Acacia woodland is the dominant vegetation type in the region. The Rift Valley Lakes Basin is known for its huge water resource potential in the country which consists of four sub-basins namely: Ziway-Shalla, Awassa, AbayaChamo and Chew Bahir basins (Table 1). Shalla is the deepest lake (266 m) while Abaya is the largest $\left(1160 \mathrm{~km}^{2}\right)$ in terms of size in the basin. The study site, ZiwayShalla sub-basin, encompasses four major interconnected lakes on its rift floor namely: Ziway, Langano, Abijata and Shalla (Table 1 and Fig. 1). These lakes together form one closed basin and a unique hydrological habitat in the region. Lake Abijata receives water from Lake Ziway via Bulbula River and from Lake Langano via Horakalo River. Lake Abijata and Shalla are terminal lakes (i.e. no outflow from such lakes) and hence known for their salty water.

The environment and the natural resources of the study area are currently under enormous pressure due to increased population pressure, agricultural investment expansion, urban expansion, mismanagement of land resources, and natural factors like recurrent drought (Jansen et al., 2007). Studies show that the woodland vegetation of the region has been declined in the expense of agricultural land expansion and continual deforestation over the last half century (Garedew et al., 2009; Biazin and Sterk, 2013; 
Temesgen et al., 2013; Ariti et al., 2015). The lakes and their feeding rivers are intensively used for domestic water use, irrigation, soda ash extraction, fishery, and recreation, while the lakes and their surrounding wetlands supported a wide variety of endemic birds (Hengsdijk and Jansen, 2006; Ayenew and Legesse, 2007). As a result of such anthropogenic pressures, land degradation became a serious threat to natural resources, environment, and livelihood in CRV area in recent decades (Ayenew and Legesse, 2007; Meshesha et al., 2012).

Table 1. Major lakes of Rift Valley Lakes Basin. (Data from JICA, 2012)

\begin{tabular}{|c|c|c|c|c|c|c|}
\hline Sub-basin & Lake & $\begin{array}{l}\text { Altitude } \\
\text { (m.a.s.l) }\end{array}$ & $\begin{array}{c}\text { Surface area } \\
\left(\mathbf{k m}^{2}\right)\end{array}$ & $\begin{array}{l}\text { Maximum } \\
\text { depth }(m)\end{array}$ & $\begin{array}{l}\text { Average depth } \\
\text { (m) }\end{array}$ & $\begin{array}{c}\text { Volume } \\
\left(\mathbf{k m}^{3}\right)\end{array}$ \\
\hline \multirow{4}{*}{ Ziway-Shalla } & Ziway & 1636 & 440 & 8.95 & 2.5 & 1.1 \\
\hline & Langano & 1582 & 230 & 47.9 & 17 & 5.3 \\
\hline & Abijata & 1578 & 205 & 14.2 & 7.6 & 1.61 \\
\hline & Shalla & 1558 & 409 & 266 & 87 & 36.7 \\
\hline Awassa & Awassa & 1697 & 129 & 22 & 11 & 1.3 \\
\hline \multirow{2}{*}{ Abaya-Chamo } & Abaya & 1285 & 1160 & 13 & 7 & 8.2 \\
\hline & Chamo & 1235 & 551 & 13 & 6 & 3.3 \\
\hline Chew Bahir & Chew Bahir & nd & nd & nd & nd & nd \\
\hline
\end{tabular}

The population in CRV has shown an accelerated growth over the last three decades with an average growth rate of about $3 \%$, and average family size of 7 . For example, the total population for three districts in CRV, namely Dugda, Adami Tulu-Jido Kombolcha and Arsi Negele, has grown from 383608 in 1994 to 546444 in 2007, and 659177 in 2016 (CSA, 1994, 2007), which indicates a sharp increase in population growth in the region. About $85 \%$ of the population of the study area is still living in a rural area (CSA, 2007), and unpublished reports indicate that rural-urban migration in search of employment has increased both at the local and national level in recent years.

Subsistence farming, the smallholder mixed rain-fed production system (Table 2), is the main economic activity for the vast majority $(85 \%)$ of the population in the region (Scholten, 2007; Melka et al., 2015). One of the developments reported in the past decades is the introduction and rapid expansion of irrigated agriculture into the region. Smallholder farming irrigation schemes, large-scale private and state domestic farms and foreign investment, particularly in horticulture and floriculture, have been established during the last decades (Hengsdijk and Jansen, 2006). Due to these major agricultural developments, high competition for available water resource becomes a major threat to lake ecosystems in the region (Hengsdijk and Jansen, 2006). In the agropastoral areas and areas with no access to irrigation, food insecurity is a major problem and a significant portion of the rural population is still relying on relief assistance from government and external agencies (Bekele et al., 2018a). This is evident from the low household yearly income generated from farming (Table 2). As confirmed by farmers and experts during discussion, one of the main causes of poverty in the CRV among others is the low level of agricultural productivity as a result of erratic rainfall and recurrent drought occurrence over the recent decades. 
Table 2. Summary of household characteristics in CRV lakes region of Ethiopia

\begin{tabular}{c|c}
\hline Household characteristics & Mean \\
\hline Gender (male, \%) & 81.82 \\
Age (years) & 42.18 \\
Education (literate, \%) & 61.72 \\
Family size (number) & 7.43 \\
Source of income (farming, \%) & 89.90 \\
Land holding size (ha) & 2.40 \\
Number of farm plots & 2.53 \\
Income (Birr*/year) & 29276.77 \\
Distance to nearest market centre (km) & 7.70 \\
\hline
\end{tabular}

*Ethiopian currency at the time of the study, 1 USD $=22.8121$ Birr

\section{Data used and sources}

The data required for this study was generated through both primary and secondary sources. 1986, 2000 and 2016 LUCC area statistics data was partly adopted from previous work of Bekele et al. (2018a). Primary data on household characteristics, socioeconomic background, historical LUCC extent, drivers and its impacts were gathered by an in-situ formal household survey (see Appendix), focus group discussion, field observations, and informal discussion with key informants, and experts working at the study site. A questionnaire with semi-structured type was designed to assess rural farmers' perception of LUC dynamics and its impacts. The survey questions covered a wide range of issues regarding socioeconomic characteristics of households, perception on LUCC extent and drivers, its livelihood and environmental impacts, and adaptation strategies to cope up with such changes. The first fieldwork was conducted in April to June 2017 and the second in September to October 2017. Important secondary socioeconomic and biophysical data was obtained from concerned governmental organizations like: Rift Valley Lakes Basin Authority, Kebele (Village) Administrative Offices (the lowest administrative unit in Ethiopia), and Woreda (District) Agricultural Offices. In addition, population data were obtained from the Central Statistical Agency (CSA, 1994, 2007). The long-term rainfall (1981-2016) and temperature (1988-2017) data for selected sites in CRV namely: Arsi Negele, Bulbula, Meki, and Ziway were taken from the National Meteorological Agency (NMA).

\section{Household survey and sampling}

The household survey was conducted in two consecutive districts found in CRV lakes region namely: Adami Tulu-Jido Kombolcha and Arsi Negele Districts which were selected based on agroecology and vulnerability to drought and LUCC in recent decades. From these Districts, representative Villages were purposively selected based on access to market and infrastructure (e.g., road), drought vulnerability (e.g., relief aid dependency in last ten years) and experience in using adaptation measures like smallscale irrigation to cope up with LUCC and drought impacts. Such basic socioeconomic and biophysical background information of the sample Villages were gathered with the help of experts who have been worked in the Districts for a long time. Accordingly, five Villages from Adami Tulu-Jido Kombolcha District namely: Welenbula, Kamo Gerbi, 
Aneno Shisho, Desta Abjata and Deneba Odansho, and three Villages from Arsi Negele District namely: Dega Hora kilo, Hadi Bossa and Rafa Hargesa, were selected for household interview and focus group discussion (Fig. 1). The households interviewed were selected randomly from each Village considering age, sex, wealth status, and literacy. The list of the households was obtained from each Village Administration Office. A total of 297 households were interviewed with an average of 37 households from each Village. In addition, at least one focus group discussion (five to ten people per group) and an interview with one key informant (elder), age at least 60, were conducted in each Village. A checklist of questions of interest was used to guide the group discussion which availed information that could not be picked up by using structured questionnaires. Additional discussion was also made with Development Agents (medium level experts assisting farmers in adoption of modern agricultural practices), at Village level and experts working at District level.

\section{Data analysis}

A combination of techniques, including Remote Sensing, GIS-based data processing and descriptive statistics were employed for data analysis. The LUC classification was done by employing a supervised maximum likelihood algorithm classification approach (Booth and Oldfield, 1989; Hogland et al., 2013; Richards, 2013) for the reference years of 1986, 2000 and 2016 using Landsat5 Thematic Mapper (TM), Landsat7 Enhanced Thematic Mapper Plus $\left(\mathrm{ETM}^{+}\right)$and Landsat8 Operational Land Imager (OLI) imageries respectively with an overall accuracies of at least $90 \%$ for each year. Accordingly, the LUC of the study area was classified in to agricultural land, dense and scattered acacia woodlands, grass/grazing land, bush/shrub land, water body, marsh/swampy area and bare land (Bekele et al., 2018a).

Data on socioeconomic characteristics of households and their perceived responses on impacts of LUCC and climate data on rainfall and temperature were coded, summarized and analyzed using descriptive statistics. Data collected through group discussions, key informants interview and field observation was analyzed qualitatively and used in the elaboration of discussion part.

Mean, standard deviation, a coefficient of variations and standardized rainfall anomalies were employed to evaluate inter-annual rainfall fluctuations and temperature variations. The standard deviation for temperature and rainfall variability was calculated using the formula in Equation 1. The coefficient of variation (Eq. 2) is used as a statistical descriptor of rainfall and temperature variability and calculated as the ratio of the standard deviation to the mean in a given period. Standardized anomalies of rainfall of the crop growing season were calculated using the formula given in Equation 3 and used to assess the frequency of droughts as in Agnew and Chappell (1999) and Bewket and Conway (2007).

$$
\begin{gathered}
\mathrm{SD}=\sqrt{\left[\sum_{\mathrm{i}=1}^{\mathrm{n}} \frac{\left(\mathrm{x}_{\mathrm{i}}-\mathrm{x}\right)^{2}}{\mathrm{n}}\right]} \\
\mathrm{CV}=\frac{\mathrm{SD}}{\mathrm{X}} * 100
\end{gathered}
$$




$$
\mathrm{SRA}=\frac{\mathrm{P}_{\mathrm{t}}-\mathrm{P}_{\mathrm{m}}}{\mathrm{SD}}
$$

where, $\mathrm{SD}=$ standard deviation, $\mathrm{CV}=$ coefficient of variation, $\mathrm{x}_{\mathrm{i}}=$ individual temperature/rainfall observation, $\mathrm{X}=$ mean rainfall/temperature, $\mathrm{n}=$ number of years considered, $\mathrm{SRA}=$ standardized rainfall anomaly, $\mathrm{P}_{\mathrm{t}}=$ annual rainfall in year $\mathrm{t}, \mathrm{P}_{\mathrm{m}}=$ long term mean annual rainfall over a period of observation (1981-2016).

\section{Results}

\section{Major land use/cover changes}

The spatiotemporal trend of LUCC in the study area for 1986, 2000 and 2016 is shown in Figure 2 for each LUC class.

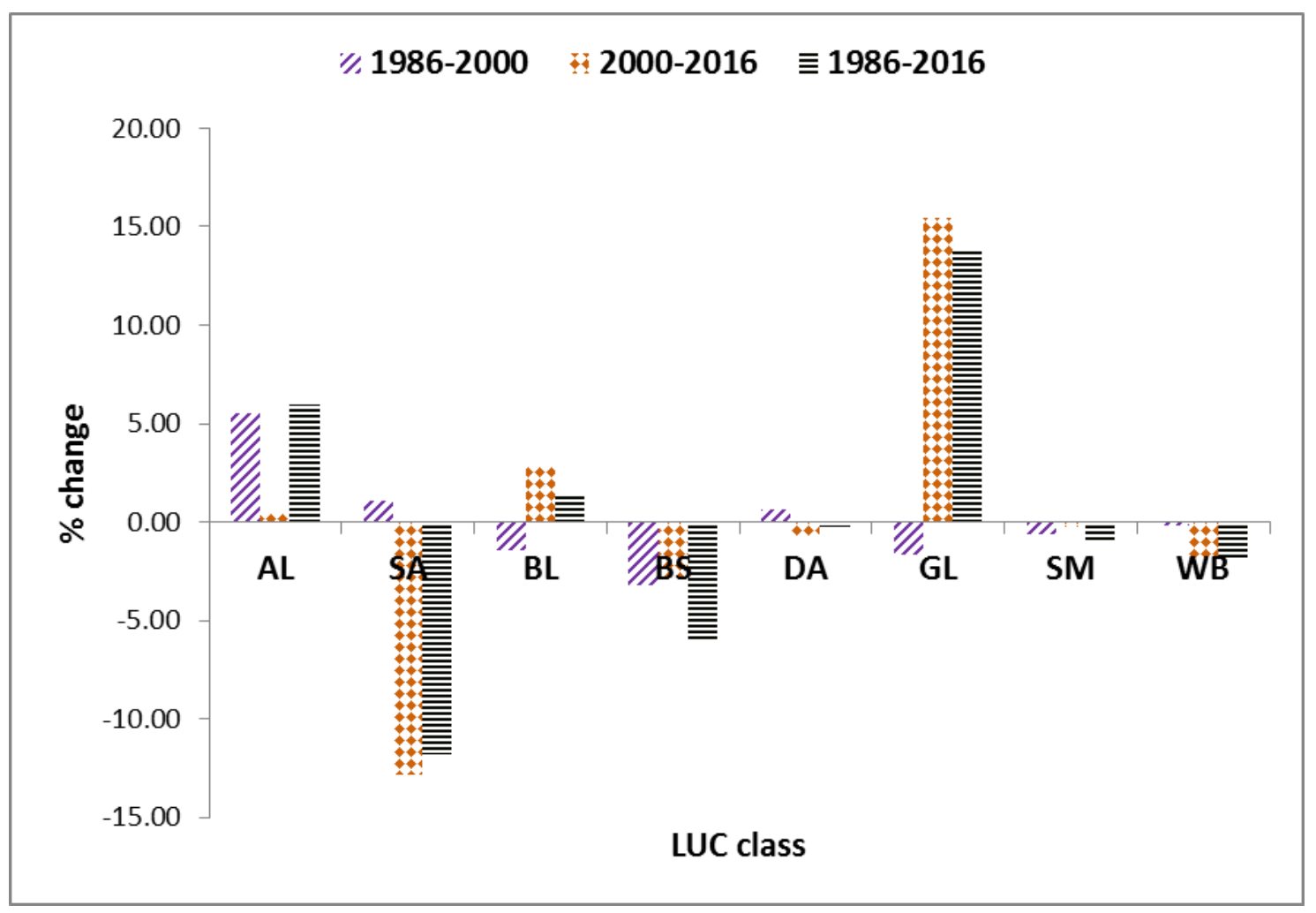

Figure 2. LUCC (\%) in CRV lakes region, adopted partly from Bekele et al. (2018a).

$A L=$ Agricultural land, $S A=$ Scattered acacia woodland, $B L=$ Bare land, $B S=$ Bush/shrubland, $D A=$ Dense acacia woodland, $G L=$ Grass/grazing land, $S M=$ Swampy/marshy land, $W B=$ Water body

Our result indicated that a tremendous LUCC has occurred in CRV lakes region over the last three decades. For instance, during the first phase of the study period (19862000), agricultural land and dense acacia woodland have increased by $39 \%$ and $23 \%$, whereas bare land and bush/shrub land have declined by $39 \%$ and $27 \%$, respectively. On the other hand, during the second phase of the study period (2000-2016), grazing land and bare land have increased by $164 \%$ and $121 \%$, while scattered acacia woodland, 
bush/shrubland and dense acacia woodland have declined by 54\%, 32\% and 27\%, respectively. This implies bush/shrubland has declined throughout both study periods. Waterbody and its associated swampy/marshy lands also declined during both study periods. Agricultural land on the other side had increased with a substantial rate until 2000, after which it showed only slight increment. During the overall study period (1986-2016), grass/grazing land, agricultural land and bare land have increased by $124 \%, 42 \%$ and $34 \%$, whereas scattered acacia woodland, bush/shrubland and swampy/marshy land have declined by $52 \%, 50 \%$ and $31 \%$, in that order.

\section{Socio-environmental impacts of land use/cover changes}

\section{Climate change and food insecurity}

Results show that LUCC has imposed a number of significant socio-environmental impacts in CRV lakes region of Ethiopia during the last three decades. This was confirmed by a number of impacts perceived by rural farmers of the study area and observed evidences from field survey (Fig. 3). About 95\% of respondent farmers mentioned climate change, particularly rainfall variability and frequent drought, as the main impact of LUCC in the region. They accused LUCC, particularly the rapid decline in vegetation coverage, as a main reason for erratic and shortage of rainfall, and an increased diurnal temperature in recent years in the study area. According to open discussion witness by focus groups, key informants, and experts, this change in climate, in turn, has directly affected the rain-fed agriculture and contributed to high food insecurity problem in the region in recent decades.

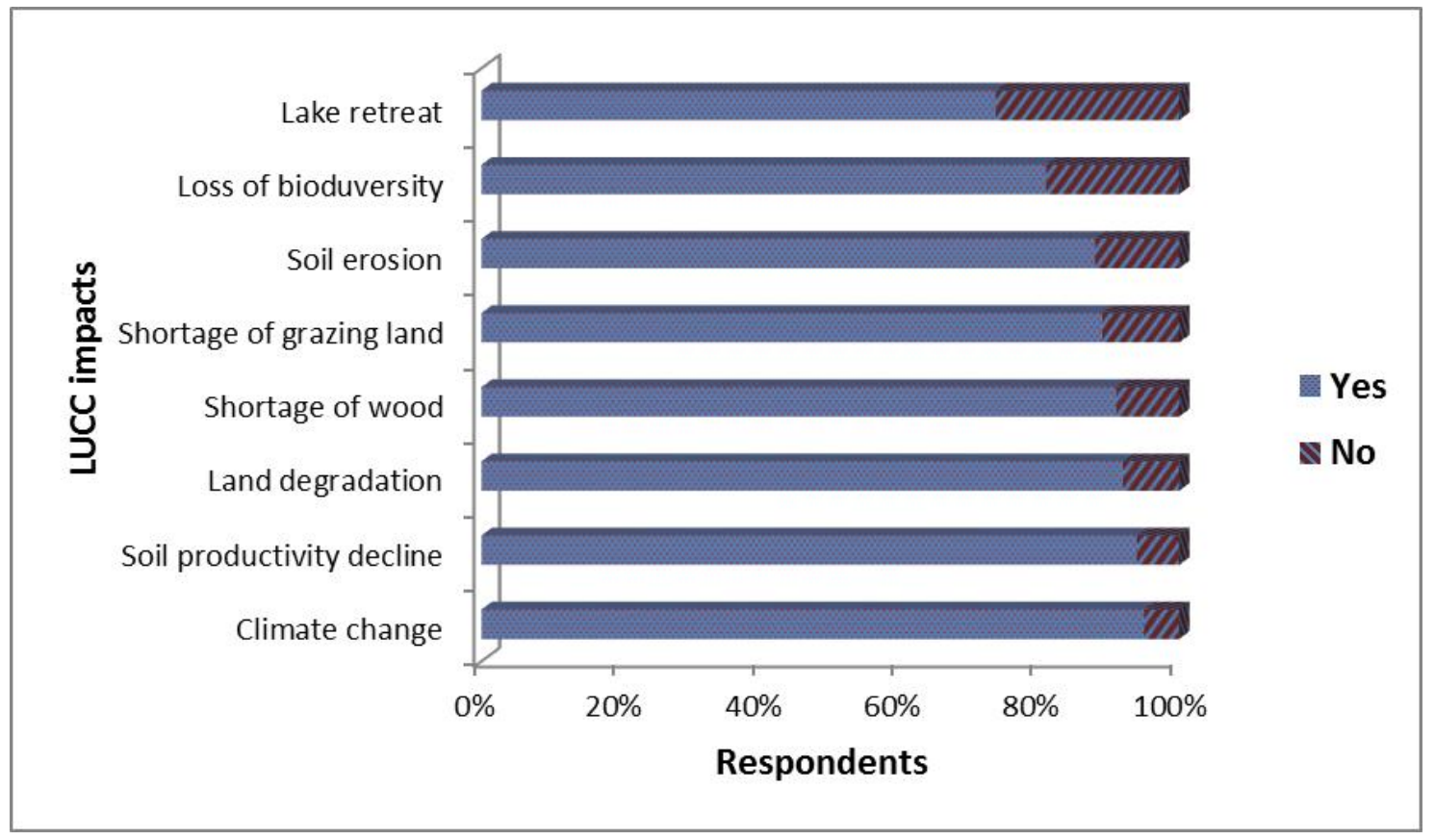

Figure 3. Impacts of LUCC as perceived by rural households (\%) in CRV lakes region of Ethiopia $(N=297)$

Table 3 summarizes rainfall and temperature statistics while Figure 4 shows the standardized rainfall anomaly of the study area. In line with household perceived 
results, the standardized rainfall anomaly of the growing season showed high interannual and inter-seasonal variability and a general decreasing trend (Fig. 4) for both Belg $(\mathrm{CV}=31 \%$, mean $=252 \mathrm{~mm} \pm 78)$ and Kirmet $(\mathrm{CV}=22 \%$, mean $=386 \mathrm{~mm} \pm 86)$ (Table 3). Of the 36 years of observation, 20 years (56\%) for Belg season and 18 years (50\%) for Kirmet season had negative anomalies, implying dry years, which is a risk for rain-fed agricultural production in the region. The coefficient of variation of rainfall is higher during the Belg season (31\%) than during Kirmet season (22\%). However, average minimum and maximum temperatures did not show significant inter-annual and inter-seasonal variation over the last three decades, though the trend line in Figure 5 indicates that it is generally hotter in recent years than in earlier years, and it is evident that an increased temperature, in turn, will increase evapotranspiration rate. The mean minimum temperature ranged from $11.5^{\circ} \mathrm{C}$ for winter season to to $14.2{ }^{\circ} \mathrm{C}$ for Kirmet season, while the mean maximum temperature ranged from $25.9^{\circ} \mathrm{C}$ for Kirmet season to $28.5{ }^{\circ} \mathrm{C}$ for Belg season. In general, the temperature has shown considerable variability during the last 30 years.

Table 3. Mean, standard deviation and coefficient of variation (\%) for long-term rainfall (1981-2016) and temperature (1988-2017) at CRV lakes region. (Data from NMA)

\begin{tabular}{c|c|c|c|c}
\hline Variable & Season & Mean & Standard deviation & Coefficient of variation \\
\hline \multirow{5}{*}{ Rainfall } & FMAM & 251.69 & 78.17 & 31.06 \\
& JJAS & 385.89 & 85.58 & 22.18 \\
& ONDJ & 102.41 & 45.91 & 44.83 \\
& Overall & 739.99 & 140.01 & 18.92 \\
\hline \multirow{5}{*}{ Minimum temperature } & FMAM & 14.00 & 1.34 & 9.58 \\
& JJAS & 14.20 & 1.23 & 8.66 \\
& ONDJ & 11.51 & 1.48 & 12.85 \\
& Overall & 13.24 & 1.26 & 9.51 \\
\hline \multirow{5}{*}{ Maximum temperature } & FMAM & 28.52 & 0.72 & 2.53 \\
& JJAS & 25.87 & 0.85 & 3.28 \\
& ONDJ & 26.96 & 0.51 & 1.90 \\
& Overall & 27.12 & 0.55 & 2.03 \\
\hline
\end{tabular}

FMAM = February to May, JJAS = June to September, ONDJ = October to January

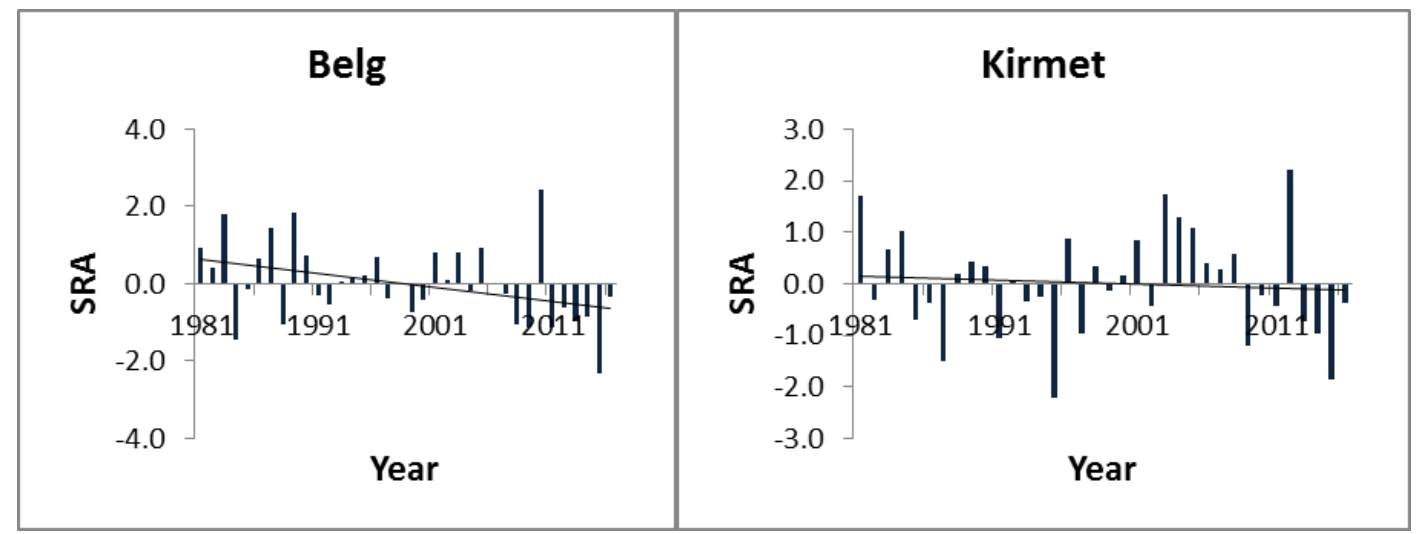

Figure 4. Standardized rainfall anomaly of the growing season (SRA) at CRV lakes region. (Data from NMA) 


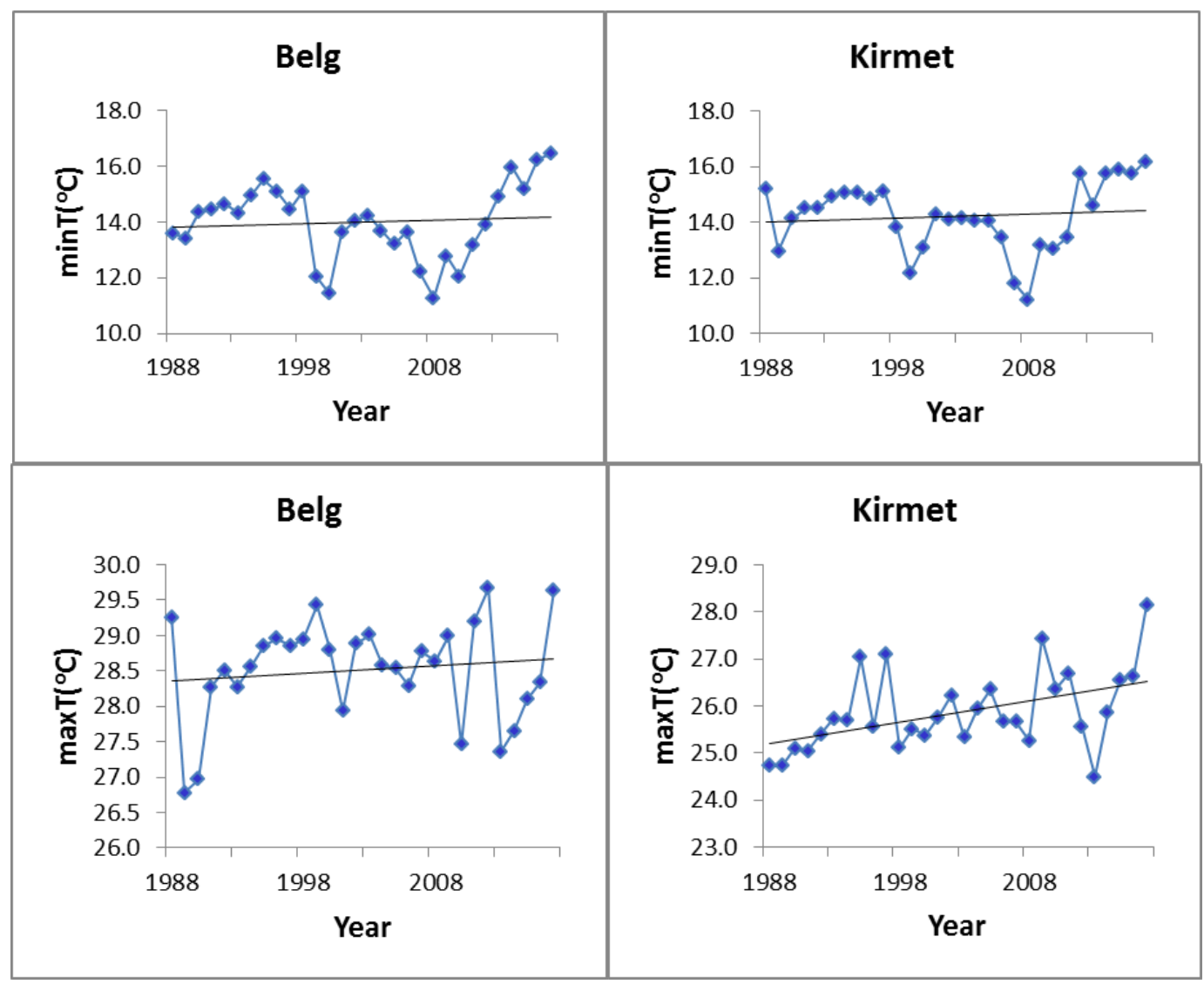

Figure 5. Trend of seasonal mean minimum (minT) and maximum (maxT) temperatures (19882017) at CRV lakes region. (Data from NMA)

\section{Land degradation}

Soil productivity decline, land degradation, and soil erosion are other major impacts of LUCC perceived by $94 \%, 92 \%$ and $88 \%$ of respondent farmers respectively (Fig. 3). Development Agents and District agricultural experts also confirmed that severe soil erosion and subsequent decline in agricultural productivity are mainly attributed to rapid LUCC in the study area over the last three decades. As observed during the field survey, indicators of land degradation (Fig. 6), specifically serious gulley erosion, expansion of bare lands, and decline/drying of streams, rivers, and lakes are among the high threats to the environment and rural livelihood in CRV lakes region. It is common to see severe gulley erosion like the one in Figure $6 a$, in cultivated lands, along a roadside, and in grazing lands. In addition to water erosion, wind erosion is also a common phenomenon observed in CRV area during the dry season. Extensive bare lands are mainly found along the shore of Lake Abijata (Fig. 6d) due to its fast retreat and water loss in recent decades. The Bulbula River was already dried due to decline in the level of Lake Ziway (its source), high water consumption for irrigation, drought and catchment degradation in general (Fig. 6c).

\section{Shortage of wood and grazing land}

Other major important impacts of LUCC mentioned by more than $89 \%$ of respondents were a shortage of wood and grazing land (Fig. 3). During the discussion, 
focus groups pointed that due to firewood shortage and lack of access to electricity and alternative energy sources, currently they were forced to use either crop residues or cow dung, or buy firewood with expensive price from nearby markets, which had been otherwise accessed from nearby woodlands/forests three decades ago. In addition, respondent households mentioned that due to a shortage of cropland and productivity decline from time to time, they were forced to change part of their previous grazing land to croplands, which contributed to a shortage of grazing land. Hence, coupled with recurrent drought, shortage of grass/grazing land has made cattle rearing the most difficult rural livelihood option, and hence most farmers have been forced to limit the number of their cattle holding in recent decades.
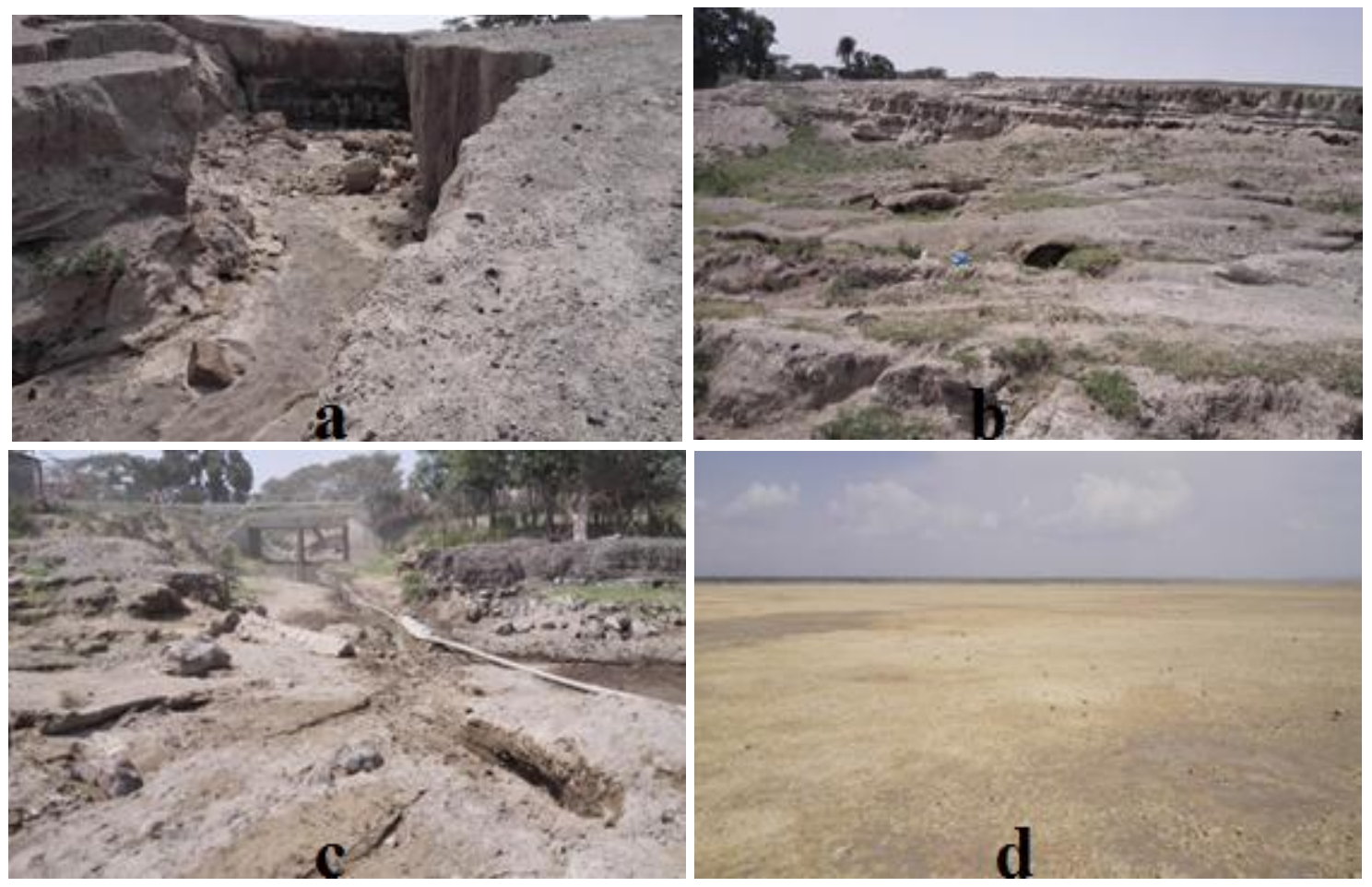

Figure 6. Indicators of land degradation in CRV lakes region of Ethiopia: (a) active gulley head; (b) bare and eroded land; (c) drying of Bulbula River which flow from Lake Ziway to Lake Abijata; and (d) retreat of Lake Abijata. (Photo by B. Bekele)

\section{Water resources degradation and biodiversity loss}

Last but very important impacts of LUCC perceived by about $81 \%$ and $74 \%$ of interviewees respectively were the loss of biodiversity and lake water retreat (Fig. 3). Drying of rivers and streams specifically of Bulbula River (Fig. 6c) and lake water loss, particularly of Lake Abijata (Fig. 6d) and Lake Ziway, was strongly emphasized by survey participants (individual households, key informants, focus groups and experts) during the discussion. Key informants (elders) confirmed that Lake Abijata now lost at least one-fourth of the area coverage it has 20 years ago.

In agreement with perceived results, the observed trend (Table $4 a$ ) and projected trend (Table $4 b)$ indicate high water resources degradation in CRV lakes region. During 34 years period, Lake Abijata lost about 51\% of its area in 1973 (Table 4a). The rate of loss is faster in recent years than in earlier years. For example, as shown in Table $4 a$, 
during 1999-2006, eight years alone, Lake Abijata lost about 42\% of its area in 1999. The projected change (Table $4 b$ ) also shows that Lake Abijata will continue to lose about $17 \%$ of its area and $1.28 \mathrm{~m}$ of its level until 2034 followed by Lake Ziway, which will be expected to lose $10.7 \%$ area and $0.57 \mathrm{~m}$ level. Such high degradation on lakes, in turn, is a major threat to biodiversity loss particularly bird and fish species inhabiting these lakes.

Table 4. Observed changes in size of Lake Abijata (1973-2006) (a) and long term projected change in level and area of four CRV lakes (2005-2034) (b). (Data from Jansen et al., 2007 and Raventós Vilalta, 2010)

\begin{tabular}{l|c|c|c|c}
\hline \multicolumn{2}{c|}{ (a) Lake Abijata observed change } & \multicolumn{3}{|c}{ (b) Projected change } \\
\hline Year & Area $\left.\mathbf{( k m}^{\mathbf{2}}\right)$ & Lake & Level (m) & Area (\%) \\
\hline 1973 & 194.00 & Ziway & -0.57 & -10.70 \\
1986 & 162.00 & Abijata & -1.28 & -17.00 \\
1999 & 163.00 & Langano & -1.08 & -3.10 \\
2006 & 95.00 & Shala & -1.74 & -0.60 \\
\hline
\end{tabular}

\section{Discussion}

In their previous studies, the authors reported the systematic and random LUCC transitions (Bekele et al., 2018a) and its principal drivers (Bekele et al., 2018b submitted) in CRV lakes region of Ethiopia. The results of these studies show that a rapid LUCC has occurred in CRV lakes region of Ethiopia in recent three decades and these changes are driven by population growth, fuelwood extraction, agricultural land expansion, charcoal making, recurrent drought and overgrazing. This unregulated change in LUC has imposed a number of socioeconomic and environmental related impacts, according to farmers' perception, experts' opinion and authors' field observation. The impacts are highly interrelated and hence further aggravate each other. These include climate change and subsequent food insecurity, land degradation, shortage of wood and grazing land, degradation of water resources and loss of biodiversity.

Climate change, particularly rainfall variability (late onset, early set-off, accidental flood, frequent drought) as confirmed by respondents and analysis of meteorological dataset, is a major problem in CRV lakes region in recent years, which is also consistent with previous studies (Biazin and Sterk, 2013; Kassie et al., 2013). This unpredictable and erratic rainfall, in turn, increased the vulnerability of rain-fed agriculture to climate change (Gizachew and Shimelis, 2014) which resulted in food insecurity and relief aid dependency of thousands of farmers in the region. Frequent drought is the main challenge to food security in East African countries in recent decades (Pricope et al., 2013; Masih et al., 2014). For instance, historical records showed that Ethiopia has experienced a repeated dry-spells hit over the last half century (Jury, 2010; Fazzini et al., 2015). One causative factor of this variability in rainfall in Ethiopia among others is believed to be the rapid change in LUC of the country, particularly massive deforestation (Gurmessa, 2015). This agrees with our starting assumption that LUCC is one potential contributor that increases climate change vulnerability in the country. It is known that LUCC has local and regional climate change effects especially through the accumulation of GHGs (Pielke, 2005; Houghton et al., 2012). In addition to increasing 
the atmospheric concentration of GHGs and therefore influencing global climate, LUCC, particularly deforestation could also affect the regional or local climate by altering the water and energy budget at the Earth's surface via changing albedo, Bowen ratio and surface moisture (Hagos et al., 2014; Ahmed et al., 2016). Studies also show that LUCC affects land surface temperature and surface moisture (Jiang et al., 2015; Pal and Ziaul, 2017), carbon balance of terrestrial environments (Houghton and Goodale, 2004), and precipitation and evapotranspiration rates and hence influencing the hydrological and climatological systems (Liu et al., 2008).

Land degradation in CRV lakes region, particularly decrease in soil productivity, severe soil erosion, expansion of bare lands and abandon lands are consequences directly linked to unregulated LUCC (e.g. deforestation) and mismanagement of land, for example, overgrazing in the region. It is known that expansion of bare lands further exposes the soil to water and wind erosion, and soil erosion, in turn, is the primary cause for deterioration in soil fertility, and productivity decline (Lal, 2001). Previous studies also reported severe land degradation and subsequent soil productivity decline in CRV region (Meshesha et al., 2012; Adimassu et al., 2013) and in other parts of Ethiopia (Taddese, 2001; Teketay, 2001; Zeleke and Hurni, 2001; Amsalu et al., 2007) which are directly or indirectly related to the rapid LUCC in the country. Studies show that LUCC, particularly extensive vegetation removal and mismanagement of croplands could accelerate soil erosion (Teketay, 2001; Nunes et al., 2011). For instance, keeping other factors constant, soil erosion is expected to be more severe on bare lands and croplands, than on forest lands (Nunes et al., 2011). Some unpublished government reports claim for an increased productivity per hectare of land in recent years in Ethiopia; but as confirmed by farmers and experts during discussion, this could be possible only for good rainy years and at the expense of high inputs (fertilizer, pesticide, herbicide, and labour) which is unaffordable by poor farming households due to high price inflation of such inputs in the country in recent years.

High shortage of wood and wood products is another critical problem faced in Ethiopia following massive deforestation in the country in general and the study site in particular. The wood shortage crisis is evident from the high price of wood products on the local market currently. The demand on wood and wood products, on the other hand, is highly increased in Ethiopia from time to time following population growth, as wood is the basic material required for construction, house furniture, energy supply, and an alternative source of income in the country (Gurmessa, 2015). The demand for wood for firewood is further exacerbated by lack of access to primary energy sources, like rare rural electrification in Ethiopia currently. On the other hand, the domestic supply base for wood products is already in its critical stage in Ethiopia in recent years. This is because the natural forest resource of the country was already lost as a result of rapid deforestation over the last half century (Teketay, 2001; Guta, 2014), whereas efforts made to fill the gap with the expansion of plantation forest is too low to supply the demand and is constrained by several management problems (Lemenih and Kassa, 2014). Such wood shortage crisis is also evident from common usage of crop residues and cow dung as firewood in both urban and rural areas of the country (Guta, 2014) which also further contribute to soil fertility and productivity decline.

The CRV lakes region is known for its huge water resource in the country; because with the exception of Lake Tana, all principal Ethiopian lakes are found within the catchment of Rift Valley Lakes Basin. These lakes are interconnected to each other and together form a closed sub-basin. However, currently there exists a high competing 
claim for land and water resources by different stakeholders in this basin, and managing these different claims to achieve sustainable development remained the most challenging and an issue of environmental and economic debate currently (Jansen et al., 2007). In CRV, land, and water resources are highly interrelated and hence any change in LUC directly affects the water and its habitats. Anthropogenic-induced activities, for example, rapid LUCC and natural processes like climate change in the region imposed a number of critical impacts on lake water resources, their associated wetlands and biodiversity (Seyoum et al., 2015). For instance, the rapid retreat of lakes' volume (e.g., Lake Abijata and Lake Ziway), drying/decline of streams and rivers (e.g., Bulbula River), and water pollution due to chemical-intensified farming (e.g., Laka Ziway) are indicators of severe lakes' degradation in the region. With current rate of retreat studies projected that Lake Abijata will totally dry within the coming 50 years (Jansen et al., 2007; Temesgen et al., 2013; Seyoum et al., 2015), and unless urgent measures are taken, Lake Ziway will be the second to share a similar fate in the coming near future. For example, the drying of Bulbula River, which discharges water from Lake Ziway to Lake Abijata, is a signal of warning for a significant decline in the level of Lake Ziway currently. The average level of Lake Ziway has decreased by approximately $0.5 \mathrm{~m}$ since 2002 which is equivalent to a loss of about 200 million $\mathrm{m}^{3}$ of water (Jansen et al., 2007). High water abstraction for irrigation, climate change, rapid LUCC and land degradation are the major factors for such severe consequences on CRV lakes (Legesse and Ayenew, 2006; Getnet et al., 2014). For instance, the irrigated land has increased from almost zero ha in 1973 to about 10000 ha in 2006 (Jansen et al., 2007), and an estimated $285 \mathrm{Mm}^{3} \mathrm{yr}^{-1}$ of water was abstracted for irrigation in 2009 alone (Getnet et al., 2014). Most of these irrigation development activities are situated in the downstream catchments of Lake Zway, which makes it the most vulnerable lake to such pressures. In addition, though the CRV lakes are endowed for tourism potential and they are being home for different migratory species of birds and fish, this biodiversity is currently highly threatened and became extremely vulnerable by such high humaninduced pressures on the habitats of these lakes (Jansen et al., 2007).

\section{Conclusions}

Based on the results obtained from comprehensive analysis, we can conclude that there has been a rapid and tremendous LUC dynamics occurred in CRV lakes region of Ethiopia. This change, in turn, has imposed adverse socioeconomic and environmental impacts during the study period. Climate change, soil productivity decline, land degradation, shortage of wood and grazing land, soil erosion, loss of biodiversity and lake retreat were the principal impacts of LUCC claimed by respondent farmers in decreasing order of percentage of respondents. The perceived impacts are in line with the results obtained from physical data analysis and eyewitness from in-situ field verification.

Previous studies in CRV and elsewhere mainly focused on spatiotemporal analysis of the extent and drivers of LUCC with little emphasis to its prolonged impacts. Apart from these studies, this study tried to integrate Remote Sensing, GIS, climatic data and socioeconomic survey to investigate LUC dynamics for the last three decades and its wider livelihood as well as environmental impacts in the CRV lakes region of Ethiopia. In addition, this study also tried to compare observed impacts of LUCC with that of farmers' perceived results which will hope to increase the scientific knowledge of the 
study area. It is also believed that the result of this study will serve as one of the information inputs to be used in formulating future policies and management plans for a rapidly changing CRV lakes region. However, this study might have limitations and hence further studies are important. For example, for a better understanding of climate change trends, it needs further research that addresses detail analysis on the extent of meteorological drought and how these could be affected by LUCC by incorporating data from wider meteorological stations in CRV lakes region. In addition, it is better to investigate the LUCC effect on environment and ecosystem functioning, for example, its effect on ecosystem services and human-wellbeing. Furthermore, it is important to assess the adaptation strategies and the constraints of farmers to overcome the impact of LUCC.

The study result implicated that LUCC has still continued in developing countries like East Africa, where the majority of the economy is directly dependent on natural resources. These rapid and extensive LUC dynamics is mainly driven by humaninduced pressures and climate change vulnerability, which has imposed significant socioeconomic and environmental impacts at the local, national and regional level. The natural resources of the study area are currently under enormous pressure, and hence the adverse impacts of LUCC observed for this study calls for urgent measures that work on the drivers, particularly population growth and options that help strengthen the adaptation capacity of farmers to cope up with climate change. High land degradation in the region needs integrated and sustainable environmental conservation activities by all stakeholders. The high demand for wood products, especially for firewood, needs strong action on plantation forest establishment and expansion of rural electrification, and improving access to alternative energy sources and efficient energy utilization technologies. Lake water and associated aquatic ecosystems degradation require immediate practice on integrated water resource management and formulation of policies that govern sustainable and efficient water use for irrigation. In general, future land use policies at local, national and regional level needs to address such rapid LUCC and the principal drivers, in order to reduce the adverse impacts and maintain the fragile ecosystems of the CRV lakes region while diversifying alternative livelihood options to feed the ever-growing population of the region.

Acknowledgements. The authors are indebted to thank the National Natural Sciences Foundation of China (Fund No. 41571176), International Cooperation and Cultivation Project of Nanjing Agricultural University (Fund No. 2018-AF-22), and The 111 Project (Fund No. B17024) by State Administration of Foreign Experts Affairs and Ministry of Education of China for financial support and encouragement in conducting this study. We are grateful to thank the Chinese Government Scholarship Council (CSC) for giving the first author a chance to pursue his Ph.D. study in China. Special thanks also go to all the staff members of Agricultural Office of the Dugda, Adami Tulu-Jido Kombolcha and Arsi Negele Districts who helped during field data collection and all the rural farmers of the three Districts who took part during the field survey. We are also pleased to acknowledge the anonymous reviewers for their helpful comments and opinions on the earlier draft of this manuscript.

\section{REFERENCES}

[1] Adimassu, Z., Kessler, A., Yirga, C., Stroosnijder, L. (2013): Farmers' perceptions of land degradation and their investments in land management: A case study in the central Rift Valley of Ethiopia. - Environmental Management 51: 989-998.

[2] Agnew, C., Chappell, A. (1999): Drought in the Sahel. - GeoJournal 48: 299-311. 
[3] Ahmed, K. F., Wang, G., You, L., Yu, M. (2016): Potential impact of climate and socioeconomic changes on future agricultural land use in West Africa. - Earth System Dynamics 7: 151-165.

[4] Amsalu, A., Stroosnijder, L., De Graaff, J. (2007): Long-term dynamics in land resource use and the driving forces in the Beressa watershed, highlands of Ethiopia. - Journal of Environmental Management 83: 448-459.

[5] Ariti, A. T., van Vliet, J., Verburg, P. H. (2015): Land-use and land-cover changes in the Central Rift Valley of Ethiopia: Assessment of perception and adaptation of stakeholders. - Applied Geography 65: 28-37.

[6] Ayenew, T. (2007): Water management problems in the Ethiopian rift: Challenges for development. - Journal of African Earth Sciences 48: 222-236.

[7] Ayenew, T., Legesse, D. (2007): The changing face of the Ethiopian rift lakes and their environs: call of the time. - Lakes \& Reservoirs: Research \& Management 12: 149-165.

[8] Bekele, B., Wu, W., Legesse, A., Temesgen, H., Yirsaw, E. (2018a): Random and systematic land use/land cover transitions in semi-arid landscapes of Ethiopian Central Rift Valley Lakes Region (East Africa). - Applied Ecology and Environmental Research 16: 3993-4014.

[9] Bekele, B., Wu, W., Legesse, A., Temesgen, H., Yirsaw, E. (2018b): Drivers of land useland cover changes in Ethiopian Central Rift Valley lakes region (East Africa). - Journal of Integrative Environmental Sciences (in press).

[10] Bewket, W., Conway, D. (2007): A note on the temporal and spatial variability of rainfall in the drought-prone Amhara region of Ethiopia. - International Journal of Climatology 27: 1467-1477.

[11] Biazin, B., Sterk, G. (2013): Drought vulnerability drives land-use and land cover changes in the Rift Valley dry lands of Ethiopia. - Agriculture, Ecosystems and Environment 164: 100-113.

[12] Booth, D., Oldfield, R. (1989): A comparison of classification algorithms in terms of speed and accuracy after the application of a post-classification modal filter. - Remote Sensing 10: 1271-1276.

[13] Brovkin, V., Sitch, S., Von bloh, W., Claussen, M., Bauer, E., Cramer, W. (2004): Role of land cover changes for atmospheric $\mathrm{CO}_{2}$ increase and climate change during the last 150 years. - Global Change Biology 10: 1253-1266.

[14] Carpio, A. J., Oteros, J., Tortosa, F. S., Guerrero-Casado, J. (2016): Land use and biodiversity patterns of the herpetofauna: The role of olive groves. - Acta Oecologica 70: 103-111.

[15] Chhabra, A., Geist, H., Houghton, R. A., Haberl, H., Braimoh, A. K., Vlek, P. L., Patz, J., Xu, J., Ramankutty, N., Coomes, O. (2006): Multiple Impacts of Land-Use/Cover Change. - In: Lambin, E. F., Geist, H. (ed.) Land-Use and Land-Cover Change: Local Process and Global Impacts. Springer-Verlag, Berlin Heidelberg, pp. 71-116.

[16] CSA (1994): The 1994 Population and Housing Census Results for Oromiya Region. Central Statistical Agency, Addis Ababa, Ethiopia.

[17] CSA (2007): The 2007 Population and Housing Census Results for Oromiya Region. Central Statistical Agency, Addis Ababa, Ethiopia.

[18] Dirmeyer, P. A., Niyogi, D., De Noblet-Ducoudré, N., Dickinson, R. E., Snyder, P. K. (2010): Impacts of land use change on climate. - International Journal of Climatology 30: 1905-1907.

[19] Fan, X., Ma, Z., Yang, Q., Han, Y., Mahmood, R. (2015): Land use/land cover changes and regional climate over the Loess Plateau during 2001-2009. Part II: interrelationship from observations. - Climatic Change 129: 441-455.

[20] Fazzini, M., Bisci, C., Billi, P. (2015): The Climate of Ethiopia. - In: Bliip, P. (ed.) Landscapes and Landforms of Ethiopia. Springer, Dordrecht, pp. 65-87. 
[21] Garedew, E., Sandewall, M., Soderberg, U., Campbell, B. M. (2009): Land-use and landcover dynamics in the central rift valley of Ethiopia. - Environmental Management 44: 683-94.

[22] Geist, H., Mcconnell, W., Lambin, E. F., Moran, E., Alves, D., Rudel, T. (2006): Causes and Trajectories of Land-Use/Cover Change. - In: Lambin, E. F., Geist, H. (ed.) LandUse and Land-Cover Change: Local Process and Global Impacts. Springer-Verlag, Berlin Heidelberg, pp. 41-70.

[23] Getnet, M., Hengsdijk, H., van Ittersum, M. (2014): Disentangling the impacts of climate change, land use change and irrigation on the Central Rift Valley water system of Ethiopia. - Agricultural Water Management 137: 104-115.

[24] Gizachew, L., Shimelis, A. (2014): Analysis and mapping of climate change risk and vulnerability in Central Rift Valley of Ethiopia. - African Crop Science Journal 22: 807818.

[25] Gurmessa, F. (2015): Forest loss and climate change in Ethiopia. - Research Journal of Agriculture and Environmental Management 4: 216-224.

[26] Guta, D. D. (2014): Effect of fuelwood scarcity and socio-economic factors on household bio-based energy use and energy substitution in rural Ethiopia. - Energy Policy 75: 217227.

[27] Hagos, S., Leung, L. R., Xue, Y., Boone, A., de Sales, F., Neupane, N., Huang, M., Yoon, J.-H. (2014): Assessment of uncertainties in the response of the African monsoon precipitation to land use change simulated by a regional model. - Climate Dynamics 43 : 2765-2775.

[28] Haines-Young, R. (2009): Land use and biodiversity relationships. - Land Use Policy 26: S178-S186.

[29] Hengsdijk, H., Jansen, H. (2006): Agricultural Development in the Central Ethiopian Rift Valley: A Desk-Study on Water-Related Issues and Knowledge to Support a Policy Dialogue. Note 375. - Plant Research International BV, Wageningen.

[30] Hogland, J., Billor, N., Anderson, N. (2013): Comparison of standard maximum likelihood classification and polytomous logistic regression used in remote sensing. European Journal of - Remote Sensing 46: 623-640.

[31] Houghton, R., Goodale, C. (2004): Effects of Land-Use Change on the Carbon Balance of Terrestrial Ecosystems. - In: Defries, R. S., Asner, G. P., Houghton, R. A. (eds.) Ecosystems and land use change. Geophysical Monograph Series 153. American Geophysical Union, Washington, DC, pp. 85-98.

[32] Houghton, R., Hackler, J. (2006): Emissions of carbon from land use change in sub-Saharan Africa. - Journal of Geophysical Research: Biogeosciences 111.

[33] Houghton, R. A., House, J., Pongratz, J., Van Der Werf, G., Defries, R., Hansen, M., Quéré, C. L., Ramankutty, N. (2012): Carbon emissions from land use and land-cover change. - Biogeosciences 9: 5125-5142.

[34] Jansen, H., Hengsdijk, H., Legesse, D., Ayenew, T., Hellegers, P., Spliethoff, P. (2007): Land and Water Resources Assessment in the Ethiopian Central Rift Valley: Project: Ecosystems for Water, Food and Economic Development in the Ethiopian Central Rift Valley. Alterra-Rapport 1587. - Alterra, Wageningen.

[35] Jiang, Y., Fu, P., Weng, Q. (2015): Assessing the impacts of urbanization-associated land use/cover change on land surface temperature and surface moisture: a case study in the Midwestern United States. - Remote Sensing 7: 4880-4898.

[36] JICA (2012): The Study on Groundwater Resources Assessment in the Rift-Valley Lakes Basin in the Federal Democratic Republic of Ethiopia (Main and Final Report). - Japan International Cooperation Agency (Kokusai Kogyo CO., LTD). Ministry of Water and Energy (MoWE), The Federal Democratic Republic of Ethiopia, Addis Ababa.

[37] Jury, M. R. (2010): Ethiopian decadal climate variability. - Theoretical and Applied Climatology 101: 29-40. 
[38] Kassie, B. T., Hengsdijk, H., Rotter, R., Kahiluoto, H., Asseng, S., Van Ittersum, M. (2013): Adapting to climate variability and change: experiences from cereal-based farming in the central rift and Kobo Valleys, Ethiopia. - Environmental Management 52: 1115-31.

[39] Kindu, M., Schneider, T., Teketay, D., Knoke, T. (2015): Drivers of land use/land cover changes in Munessa-Shashemene landscape of the south-central highlands of Ethiopia. Environmental Monitoring and Assessment 187: 452.

[40] Lal, R. (2001): Soil degradation by erosion. - Land Degradation \& Development 12: 519539.

[41] Lambin, E. F., Ehrlich, D. (1997): Land-cover changes in sub-Saharan Africa (19821991): Application of a change index based on remotely sensed surface temperature and vegetation indices at a continental scale. - Remote Sensing of Environment 61: 181-200.

[42] Lambin, E. F., Meyfroidt, P. (2011): Global land use change, economic globalization, and the looming land scarcity. - Proceedings of the National Academy of Sciences 108: 34653472.

[43] Lambin, E. F., Geist, H. J., Lepers, E. (2003): Dynamics of land-use and land-cover change in tropical regions. - Annual Review of Environment and Resources 28: 205-241.

[44] Legesse, D., Ayenew, T. (2006): Effect of improper water and land resource utilization on the central Main Ethiopian Rift lakes. - Quaternary International 148: 8-18.

[45] Lemenih, M., Kassa, H. (2014): Re-greening Ethiopia: history, challenges and lessons. Forests 5: 1896-1909.

[46] Liu, M., Tian, H., Chen, G., Ren, W., Zhang, C., Liu, J. (2008): Effects of land-use and land-cover change on evapotranspiration and water yield in China during 1900-2000. Journal of the American Water Resources Association 44: 1193-1207.

[47] Macgregor, D. (2015): History of the development of the East African Rift System: a series of interpreted maps through time. - Journal of African Earth Sciences 101: 232252.

[48] Maharjan, K. L., Joshi, N. P. (2013): Climate Change, Agriculture and Rural Livelihoods in Developing Countries. - Springer, Japan, pp. 1-23.

[49] Masih, I., Maskey, S., Mussá, F., Trambauer, P. (2014): A review of droughts on the African continent: a geospatial and long-term perspective. - Hydrology and Earth System Sciences 18: 3635 .

[50] Matano, A.-S., Kanangire, C. K., Anyona, D. N., Abuom, P. O., Gelder, F. B., Dida, G. O., Owuor, P. O., Ofulla, A. V. (2015): Effects of land use change on land degradation reflected by soil properties along Mara River, Kenya and Tanzania. - Open Journal of Soil Science 5: 20.

[51] Melka, Y., Kassa, H., Ketema, M., Abebaw, D., Schmiedel, U. (2015): The effect of drought risk perception on local people coping decisions in the Central Rift Valley of Ethiopia. - Journal of Development and Agricultural Economics 7: 292-302.

[52] Meshesha, D. T., Tsunekawa, A., Tsubo, M. (2012): Continuing land degradation: causeeffect in Ethiopia's Central Rift Valley. - Land Degradation \& Development 23: 130143.

[53] Mutiibwa, D., Kilic, A., Irmak, S. (2014): The effect of land cover/land use changes on the regional climate of the USA high plains. - Climate 2: 153-167.

[54] Mutoko, M. C., Hein, L., Bartholomeus, H. (2014): Integrated analysis of land use changes and their impacts on agrarian livelihoods in the western highlands of Kenya. Agricultural Systems 128: 1-12.

[55] Nunes, A. N., De Almeida, A. C., Coelho, C. O. (2011): Impacts of land use and cover type on runoff and soil erosion in a marginal area of Portugal. - Applied Geography 31: 687-699.

[56] Pacheco-Angulo, C., Vilanova, E., Aguado, I., Monjardin, S., Martinez, S. (2017): Carbon emissions from deforestation and degradation in a forest reserve in Venezuela between 1990 and 2015. - Forests 8: 291. 
[57] Pal, S., Ziaul, S. (2017): Detection of land use and land cover change and land surface temperature in English Bazar urban centre. - The Egyptian Journal of Remote Sensing and Space Science 20: 125-145.

[58] Pang, C., Yu, H., He, J., Xu, J. (2013): Deforestation and changes in landscape patterns from 1979 to 2006 in Suan County, DPR Korea. - Forests 4: 968-983.

[59] Pielke, R. A. (2005): Land use and climate change. - Science 310: 1625-1626.

[60] Polasky, S., Nelson, E., Pennington, D., Johnson, K. A. (2011): The impact of land-use change on ecosystem services, biodiversity and returns to landowners: a case study in the state of Minnesota. - Environmental and Resource Economics 48: 219-242.

[61] Pricope, N. G., HUsak, G., Lopez-Carr, D., Funk, C., Michaelsen, J. (2013): The climatepopulation nexus in the East African Horn: Emerging degradation trends in rangeland and pastoral livelihood zones. - Global Environmental Change 23: 1525-1541.

[62] Raventós Vilalta, E. (2010): Water Resources Management in the Central Rift Valley in Ethiopia. - MSc Thesis. Universitat Politecnica Catalunya, Spain.

[63] Richards, J. A. (2013): Supervised Classification Techniques. - In: Richards, J. A. (ed.) Remote Sensing Digital Image Analysis. Springer-Verlag, Berlin, Heidelberg, pp 247318.

[64] Scholten, W. (2007): Agricultural Development and Water Use in the Central Rift Valley of Ethiopia: A Rapid Appraisal. - Internship Report. University of Twente, Enshde, The Netherlands.

[65] Seyoum, W. M., Milewski, A. M., Durham, M. C. (2015): Understanding the relative impacts of natural processes and human activities on the hydrology of the Central Rift Valley lakes, East Africa. - Hydrological Processes 29: 4312-4324.

[66] Taddese, G. (2001): Land degradation: a challenge to Ethiopia. - Environmental Management 27: 815-824.

[67] Teketay, D. (2001): Deforestation, wood famine, and environmental degradation in Ethiopia's highland ecosystems: urgent need for action. - Northeast African Studies 8: 53-76.

[68] Temesgen, H., Nyssen, J., Zenebe, A., Haregeweyn, N., Kindu, M., Lemenih, M., Haile, M. (2013): Ecological succession and land use changes in a lake retreat area (Main Ethiopian Rift Valley). - Journal of Arid Environments 91: 53-60.

[69] Temesgen, H., Wu, W., Legesse, A., Yirsaw, E., Bekele, B. (2018): Landscape-based upstream-downstream prevalence of land-use/cover change drivers in southeastern rift escarpment of Ethiopia. - Environmental Monitoring and Assessment 190: 166.

[70] Tsegaye, D., Moe, S. R., Vedeld, P., Aynekulu, E. (2010): Land-use/cover dynamics in Northern Afar rangelands, Ethiopia. - Agriculture Ecosystems \& Environment 139: 174180.

[71] Turner, B., Meyer, W. B., Skole, D. L. (1994): Global land-use/land-cover change: towards an integrated study. - Ambio 23: 91-95.

[72] Turner, B. L., Lambin, E. F., Reenberg, A. (2007): The emergence of land change science for global environmental change and sustainability. - Proceedings of the National Academy of Sciences 104: 20666-20671.

[73] Vitousek, P. M. (1994): Beyond global warming: ecology and global change. - Ecology 75: 1861-1876.

[74] Wan, L., Zhang, Y., Zhang, X., Qi, S., Na, X. (2015): Comparison of land use/land cover change and landscape patterns in Honghe National Nature Reserve and the surrounding Jiansanjiang Region, China. - Ecological Indicators 51: 205-214.

[75] Wortley, L., Hero, J. M., Howes, M. (2013): Evaluating ecological restoration success: a review of the literature. - Restoration Ecology 21: 537-543.

[76] Yirsaw, E., Wu, W., Temesgen, H., Bekele, B. (2016): Effect of temporal land use/land cover changes on ecosystem services value in coastal area of China: The case of Su-XiChang region. - Applied Ecology and Environmental Research 14: 409-422. 
[77] Zeleke, G., Hurni, H. (2001): Implications of land use and land cover dynamics for mountain resource degradation in the Northwestern Ethiopian highlands. - Mountain Research and Development 21: 184-191.

\section{APPENDIX}

\section{Household survey questionnaire}

Name of respondent (Household Head): PA Name:

Woreda (District) Name: Date of interview:

Name and signature of enumerator:

\section{Household characteristics}

1. Wealth category of a household: a) Poor [] $\quad$ b) Medium [] $\quad$ c) Relatively better-off []

2. Household head sex, age, marital status, family size, education level and occupation

\begin{tabular}{|c|c|c|c|c|c|c|c|}
\hline \multirow{2}{*}{ Name } & \multirow{2}{*}{ Sex } & \multirow{2}{*}{ Age } & \multirow{2}{*}{$\begin{array}{c}\text { Marital } \\
\text { Status }\end{array}$} & \multirow{2}{*}{$\begin{array}{c}\text { No. of family } \\
\text { members }\end{array}$} & \multirow{2}{*}{$\begin{array}{l}\text { Level of } \\
\text { education }\end{array}$} & \multicolumn{2}{|c|}{ Occupation } \\
\hline & & & & & & Primary & Secondary \\
\hline
\end{tabular}

3. Years of experience as a farmer: a) 5-10 []

b) $11-15[]$

c) $16-20[]$

d) $21-25[]$
e) 26-30 []
f) $31-35[]$
g) 36- 40[]

4. Main livelihood activity you engaged in:

- before certain years:
a) Mixed farming []
b) Pastoralist []
c) Agro-pastoralist []
d) Off-farm income []
e) Others (specify)

- Currently:
a) Mixed farming []
b) Pastoralist []
c) Agro-pastoralist []
d) Off-farm income []
e) Others (specify)

\section{Land tenure and land holding size}

5. Means of land acquisition (tenure): a) Distribution []

b) Inheritance []
c) Gift []
d) Share cropping []
e) Renting []

6. No of plots of land you own? a) One []

b) Two []

c) Three []

d) Four []

e) Five or more []

7. The total size of all your land in 'Timad'/hectares:

8. Your land holding is currently: a) Certified [] $\quad$ b) Not certified []

\section{Income sources}

9. Main source of household subsistence income and cash: a) Farm (crops consumed \& sold, livestock consumed and sold, and others, specify)

b) Non-farm (petty trading: sale of fire wood, charcoal, bole soil, sand, vegetable, grain and others, labor outside the local area, remittance, fishing, private or government job e.g. teaching, health service) []

c) Others (Specify) 
10. If your main source of income is non-farm activities, does it enable you to buy all your household basic necessities? a) Yes [] $\quad$ b) No []

Specify the amount of non-farm income you get per year (Birr).

11. Your farm income: a) during 'good' year (Birr/Quintal): b) during 'moderate' year (Birr/Quintal): c) during 'bad' year (Birr/Quintal):

12. Do you have saving in 'good' year?: a) Yes [specify amount] b) No []

13. Your household major expenditures: a) Purchase of grain []

b) Buy food ingredients (salt, food oil, etc.) [] c) Buy seeds (local/improved) [] d) Buy fertilizer []
e) School fees []
f) Government tax []
g) Social affairs ('edir', 'serg', etc.) []
h) Others (specify)

\section{Energy sources}

14. Main sources of fuel for cooking \& heating: a) Firewood []

b) Charcoal []
c) Crop residues []
d) Kerosene []
e) Animal dung []
f) Others (specify) []

15. The main source of your fire wood: a) Own farm [] b) Others' farm []
c) Communal woodland []
d) Market []
e) Others (specify)

\section{Crop production}

16. Area of your crop land during the last 30 years:
a) Decrease []
b) Increase []
c) No change []

17. Crop yield per hectare of your major crops during specified periods (quintal):

\begin{tabular}{|c|l|l|l|l|l|l|l|l|}
\hline & \multicolumn{7}{|c|}{ Crop Type } & \\
\hline Yield/hectare & Maize & 'Teff' & Wheat & Sorghum & Potato & & & \\
\hline 20 years before & & & & & & & & \\
\hline 10 years before & & & & & & & & \\
\hline 5 years before & & & & & & & & \\
\hline Currently & & & & & & & & \\
\hline
\end{tabular}

18. If crop yield per hectare of your land decreased from time to time, in your opinion, mention major causes of this yield reduction. a) Erratic rainfall [] b) Improved seed scarcity and high price []
c) Unaffordable price of fertilizer []
d) Shortage of plowing oxen []
e) Soil degradation (erosion, low fertility) [] f) Prevalence of pests, diseases and weeds []
g) Lack of credit [] h) Others (specify)

\section{Livestock production}

19. In case you own livestock, what is your major source of fodder for your animals?
a) Grazing land
b) Crop residues []
c) Forest reserve areas []
d) Market []
e) Others (specify)

20. Did you observed any reduction or disappearance of palatable herbs, grass and trees in the grazing areas during last ten years? a) Yes[] b) No []

21. In which season/s of the year you face more shortage of livestock feed and how do you overcome this problem? 
22. The types and number of livestock you own:
a) Cattle (Cows, Oxen, Heifer, Bulls, calves) []
b) Goat []
c) Sheep []
d) Chicken []
e) Donkey []
f) Horse []
g) Mule []

23. What is the trend of the livestock you own in terms of their number and type over the past 30 years?
a) Decreasing []
b) Increasing []
c) No change []

24. If decreasing, what are the major reasons, in the order of importance?

a) Lack of fodder [] b) Shortage of grazing land [] c) Disease prevalence and lack of veterinary services [] d) Drought \& shortage of water [] e) Others (specify)

\section{Land use/cover change (LUCC) perception}

25. Did you observed any LUCC over the last three decades? a) Yes [

b) No []

26. How do you see the trend of LUCC over the last 30 years?

\begin{tabular}{|c|c|c|c|c|}
\hline \multirow{2}{*}{ No } & LUC type & \multicolumn{3}{|c|}{ Change observed } \\
\hline & Dense wood land (forest) & & Decrease & No change \\
\hline 1 & Scattered wood land & & & \\
\hline 2 & Grazing land & & & \\
\hline 4 & Cultivated land & & & \\
\hline 5 & Water bodies & & & \\
\hline 6 & Bare land & & & \\
\hline 7 & Settlement areas & & & \\
\hline 8 & \multicolumn{3}{|c|}{} \\
\hline
\end{tabular}

27. What do you think are the major causes/drivers for LUCC in the last three decades?
a) Population pressure []
b) Agricultural expansion []
c) Over grazing []
d) Fuel wood extraction []
e) Charcoal making []
f) Settlement []
g) Drought (climate change) []
h) Agricultural investment [] i) Livelihood change [] j) Government policy \& institutional changes []
k) Social unrest [] 1) Market \& infrastructure access m) Others (specify)

28. What major impacts of LUCC you observed on your livelihood/environment?
a) Soil fertility/productivity decline []
b) Soil erosion []
c) Land degradation []

d) Lake retreat [ ] $\quad$ e) Climate change/drought [] $\quad$ f) Loss of biodiversity []
g) Shortage of wood []
h) Shortage of grazing land []
i) Others (specify)

\section{Climate change perception}

29. Did you observed any climate change over the last three decades? a) Yes [] b) No []. If your answer to question 29 is 'Yes', answer questions 30-43.

30. Trend of rainfall amount during main rainy season (Kirmet) over the last one decade:
a) Decreased []
b) Increased []
c) No change []

31. Trend of rainfall amount during small rainy season (Belg) over the last one decade:
a) Decreased []
b) Increased []
c) No change []

32. Trend of rainfall of Kirmet season over the last one decade:
a) Coming late []
b) Coming early []
c) Early set-off []
d) Frequent dry spells []
e) Increased intensity in few period [] f) More erratic [] g) No change observed [] 
33. Trend of rainfall of Belg season over the last one decade:
a) Coming late []
b) Coming early []
c) no rain in some years []
d) Normal []

34. Temperature trend over the last one decade:
a) Increased []
b) Decreased []
c) No change []

35. Have you observed any drought occurrence over the last three decades?

a) Yes [] b) No []. If yes, how frequent does it occurred? a) Once 2-5 years []

b) Once 5-10 years [] c) Once 10 years []

36. The most disastrous drought you ever observed occurred in the year/s:

37. Have you observed any flood occurrence over the last three decades? a) Yes [] b) No [] If yes, how frequent it has occurred? a) Every year [] b) Every two year []

38. The most disastrous flood you ever observed occurred in the year/s:

39. What do you think is the causes for climate change?
a) Deforestation []
b) Overgrazing []
c) Agricultural expansion []
d) Urbanization []
e) Industrial wastes []
f) Others (specify)

40. What are the major impacts of climate change on your livelihood and environment?
a) Total crop failure []
b) Yield decrease []
c) Pest and disease prevalence[]
d) Decrease in streams and lakes volume []
e) Flood and soil erosion []

f) LUCC [] g) Others (specify)

41. Which adaptation measures did you take to cope up with climate change? Answer by (Yes/No)
a) Planting trees []
b) Soil and water conservation []
c) Changing crop/animal variety []
d) Changing planting date []
e) Changing crop type []
f) Using irrigation []
g) Crop diversification [] h) Off-farm employment [] $\quad$ i) Destocking livestock [] j) Asking for disaster relief [] k) Seasonal migration [] $\quad$ l) Storing livestock feed for dry periods []
m) Others (specify)
n) Doing nothing []

42. What are the barriers that hinder you from using adaptation measures?
a) Lack of early warning/information []
b) Lack of access to irrigation []
c) Shortage of labor []
d) Lack of resources (money, input) []
e) Lack of external support []
f) Shortage of land []
g) Others (specify)

43. Which of the following livelihood/ land use type you prefer to better cope up with climate change in the future?
a) Mixed farming
b) Agro pastoralist
C) Pastoralist

\section{Perception on environmental degradation and conservation}

44. Have you ever experienced soil degradation incidence on your farm? a) Yes[] b) No[]

45. If you answered "Yes", mention the indicators. a) Decreased crop productivity[]
b) Loss of topsoil []
c) Other (specify)

46. Soil fertility status of your land currently: a) Poor[] b) Moderate[] c) Relatively fertile[]

47. Traditional land rehabilitation measures used for mitigating soil fertility problems:
a) Addition of compost []
b) Crop rotation []
c) Fallowing []
d) Ploughing once []
e) Repeated tillage []
f) Others (specify) 
48. The major causes of forest decline in your area?
a) Expansion of cropland []
b) Illegal cutting of wood []
c) Over-grazing []
d) Government weak forest law enforcement []
e) Others (specify)

49. What type of aquatic habitats (rivers, wetlands, lakes) degradation problem you observed?
a) Drying/decreasing of water volume []
b) Pollution []
c) Excessive water withdraws for irrigation []
d) Introduction of invasive species []
e) Others specify

\section{Market and infrastructural access, and institutional support}

50. Distance to the nearest market center $(\mathrm{Km})$ : and distance to the nearest main road $(\mathrm{Km})$ :

51. Transport type used to sell your produce: a) Public transport []

b) Donkey back []
c) Donkey cart []
d) Others (specify)

52. Do you have any access to the following supports? (Answer by saying Yes/No)
a) Credit []
b) Inputs (seed, fertilizer) []
c) Training []
d) Extension on field support []
e) Farmer-to-farmer skill exchange []
f) Weather broadcast []
g) One-to-five social network []
h) Infrastructures (Tele, road, health center, water supply etc.).

\section{Open-ended questions for key informants, focus groups and local experts}

1. How you observed the LUC type and change:
- $\quad$ Before the 'Derg' regime (before 1974)
- During 'Derg' regime (1974-1990)
- $\quad$ During the current government (since 1991 to the present)

2. What do you think are the major causes of LUCC?

3. What impacts does LUCC brought on people's livelihood and environment of the area?

4. How you observed the trend of climate variability (temperature, rainfall) and extremes (drought, flood, disease prevalence etc.) occurrence during the last three decades?

5. What do you think are the major causes of climate change in the area?

6. What impacts does climate change brought on peoples livelihood and environment? 
7. What impacts does climate change brought on peoples livelihood and environment?

8. What measures you and other farmers took to cope up with the impacts of climate change?

9. What are the barriers to climate change adaptation in the area?

10. What are the extent, cause and impact of aquatic habitats (rivers, lakes, wetlands) degradation you observed in this area?

11. What measures you expect from the government and community to safeguard degraded aquatic habitats?

\section{Thank you for your cooperation!}

